\title{
Indigenous knowledge on common medicinal plants among Raji Community of Surkhet district, mid-western Nepal
}

\author{
Lal Bahadur Thapa \\ Central Department of Botany, Tribhuvan University, Kirtipur, Kathmandu, Nepal \\ Email:lal_thapa25@yahoo.com
}

\begin{abstract}
Rajis are one of the endangered indigenous tribe of Nepal distributed natively in Surkhet. In present situation the Rajis are in great pressure to change their ways of practice, belief, decision making and harvesting plant resources due to increasing population, migration and modernization. The present paper highlights the indigenous knowledge and practice of medicine preparation from common ten medicinal plants of their localities, transformation of the knowledge and response of respondents on conservation and management of medicinal plants.
\end{abstract}

Key words: Medicinal plants, indigenous knowledge, Raji community, conservation, extinction, ailments

\section{Introduction}

Nepal is one of the richest countries in cast, cultural and traditional diversity. The indigenous nationalities have their own mother tongue, folk culture, beliefs and traditional healing practices (Bhattachan, 2000). Rajis are one of the endangered indigenous tribe of Nepal distributed natively in Surkhet and have migrated to Kailali, Kanchanpur, Dang and Bardia districts of Nepal. The Rajis used to lead a nomadic life in the past (Gautam \& Thapa Magar, 1994).

Many indigenous communities abandon their traditional customs and thereby lose their plant knowledge over time (Benzet et al., 2000). The indigenous knowledge and practices of Rajis are in danger of loss due to great pressure to change the ways of practice, belief, decisionmaking and harvesting plant resources by various factors such as migration and modernization.

Some important earlier documentation on the traditional healing practices of different ethnic casts of Nepal has been made by Bhattarai (1989), Manandhar (1990, 1991), Acharya (1996), Manandhar (1998), Siwakoti and Siwakoti (1998), Joshi et al. (1999), Rai (2004) and Acharya and Acharya (2009).

\section{Materials and Methods}

A survey using questionnaire, oral interview and group discussion was conducted at two VDCs (Uttarganga \& Chhinchu) of Surkhet district inhabitated by Raji community. According to census 2001 the population of Rajis was 174 in Chhinchu VDC and 46 in Uttarganga VDC. Participatory approach was used in which Raji people contributed their knowledge acquired over time on the use of common 10 medicinal plants. The visit was done in August 17 to 25, 2012. 
The Key informants were identified after preliminary discussion. Information about medicinal uses of plants was collected by interviewing elders, traditional healers, farmers and students of the community using a semi-structured open-ended questionnaire. Name of plants, their medicinal value and other information was confirmed by focal group discussion. The specimens were collected, photographed, dried and mounted on herbarium sheets using standard methods (Martin, 1995), and identified using relevant literature (Hara et al., 1982; Polunin \& Stainton, 1984; Press et al., 2000).

\section{Result and Discussion}

\section{Use of common medicinal plants by Rajis of Surkhet}

Rajis have a rich indigenous knowledge on practice and use of different plants against various diseases but this knowledge is in the risk of being extinction due to decreasing interest of younger generations, modernization, migration from original land and cultural transformation. The indigenous knowledge is passed on orally from generation to generation without keeping any written records. Therefore, the lack of written document also reveals the chances of losing the valuable tradition forever. In view of this aspect, it is necessary to preserve and properly document the knowledge, practice and utilization of various plants. A total of 9 common medicinal plant species were selected in this work to understand the level of indigenous knowledge, response on use and practice, conservation or management and knowledge transformation in Raji community in Surkhet district (Tab. 1).

Table 1. Common medicinal plants used by Rajis in Surkhet.

\begin{tabular}{|c|c|c|c|c|}
\hline SN Scientific name (family) & Nepali/Raji name & Disease & Parts u & Mode of use \\
\hline 1 Acorus calamus L. (Araceae) & Bojho/Bach & Cough, cold & Root & Juice \\
\hline $\begin{array}{cl}2 \text { Tinospora sinensis (Lour.) } \\
\text { Merr. (Menispermaceae) }\end{array}$ & Gurjo/Gugre gano & Diarrhea, gastric & Tuber & Juice \\
\hline $\begin{array}{l}3 \text { Achyranthes aspera L. } \\
\text { (Amaranthaceae) }\end{array}$ & Ulte kuro/Ulte kura & $\begin{array}{l}\text { Loss of appetite, } \\
\text { nausea }\end{array}$ & Root & Juice \\
\hline $\begin{array}{l}\text { Asparagus racemosus Willd. } \\
\text { (Liliaceae) }\end{array}$ & Kurilo/Kurila & $\begin{array}{l}\text { Bone fracture, } \\
\text { stomach problem }\end{array}$ & Root & Paste \\
\hline $\begin{array}{l}5 \text { Aegle marmelos (L.) Correa } \\
\text { (Rutaceae) }\end{array}$ & Bel/Bela & $\begin{array}{l}\text { Gastric, } \\
\text { constipation }\end{array}$ & Fruit & Fruit \\
\hline $6 \begin{array}{l}\text { Cuscuta reflexa Roxb. } \\
\text { (Convolvulaceae) }\end{array}$ & $\begin{array}{l}\text { Akash beli/Akase } \\
\text { beli }\end{array}$ & $\begin{array}{l}\text { Jaundice, dandruff, } \\
\text { removal of placenta }\end{array}$ & $\begin{array}{l}\text { Whole } \\
\text { plant }\end{array}$ & Plant juice \\
\hline $\begin{array}{l}7 \text { Cissampelos pareira } \mathrm{L} . \\
\text { (Menispermaceae) }\end{array}$ & Batul pate/Khalite & $\begin{array}{l}\text { Stomachache, } \\
\text { dysentery }\end{array}$ & Root & Juice \\
\hline $\begin{array}{l}\text { Centella asiatica (L.) Urb. } \\
\text { (Uumbelliferae) }\end{array}$ & $\begin{array}{l}\text { Ghod tapre/Ghod } \\
\text { tapre }\end{array}$ & $\begin{array}{l}\text { Stomach problem, } \\
\text { fever, }\end{array}$ & $\begin{array}{l}\text { Entire } \\
\text { plant }\end{array}$ & Juice \\
\hline $\begin{array}{l}9 \text { Imperata cylindrica (L.) P. } \\
\text { Beauv. (Gramineae) }\end{array}$ & Siru/Siru & $\begin{array}{l}\text { Deworming, } \\
\text { antihelminthic }\end{array}$ & Root & Juice \\
\hline
\end{tabular}

\section{Respondent's age class}

The study sought to acquire an understanding of the Raji's indigenous knowledge on listed common medicinal plants, use practice and transformation. The age group of the respondent was found to range from 17 to 72 . Total 39 respondents were chosen for the questionnaire survey. Old aged people above 50 years were few in number at both the VDCs (Uttarganga 
and Chhinchu). Out of 39 respondents $38.46 \%$ were of $17-30$ years age, $38.46 \%$ were $31-50$ age group and $23.7 \%$ were above 50 years. They were categorized as young, adult and old (Fig. 1).

\section{Knowledge on medicine preparation}

Usually the medicine is prepared by head of the family or traditional healer. Respondents were asked to indicate their understanding in medicine preparation. The majority of respondents $74 \%$ were found that they can prepare medicine from medicinal plant parts, $26 \%$ of the respondents were found unable to prepare medicine and used to go head of the family or traditional healers (Fig. 2).



Figure 1. Age groups of respondents.



Figure 2. Respondent's knowledge on medicine preparation.

\section{Age and knowledge of medicine preparation}

The study indicated that the knowledge on medicine preparation increases by the increasing level of age of the respondents. It was found that $100 \%$ old age group respondents had knowledge (skill) on medicine preparation followed by adult class $(93 \%)$ and young class respondents $(40 \%)$. It showed that there was great lack of knowledge transformation from adults to young generations (Fig. 3).

\section{Knowledge transformation about the use of medicinal plant}

The knowledge about the use of medicinal plant species among Raji community was found restricted to old aged people. The sources of information and dissemination mechanisms are one of the basic factors for an individual to acquire knowledge. Among 29 knowledgeable respondents, majority (12) of them claimed that they have learnt the knowledge from their family head i.e., parents and grandparents, 9 of them claimed that they have learnt from traditional healers and 8 respondents claimed that they have learnt from their relatives (Fig. 4)

\section{Response on medicinal plant conservation and management}

To explore the Raji peoples' opinion on conservation about the medicinal plant species, respondents were requested to give their opinion. Some of the respondents mentioned "Yes we have to conserve the medicinal plants in our community forest. These respondents were categorized as good respondents indicated by "good". Other respondents were categorized as "very good". Out of 39 respondents $30(77 \%)$ respondents showed "very good" response 
and $9(36 \%)$ showed "good" response. Nobody gave negative response about the conservation and management of medicinal plants (Fig. 5). Therefore, Rajis were conscious about conservation and management of medicinal plants in their community forestry.

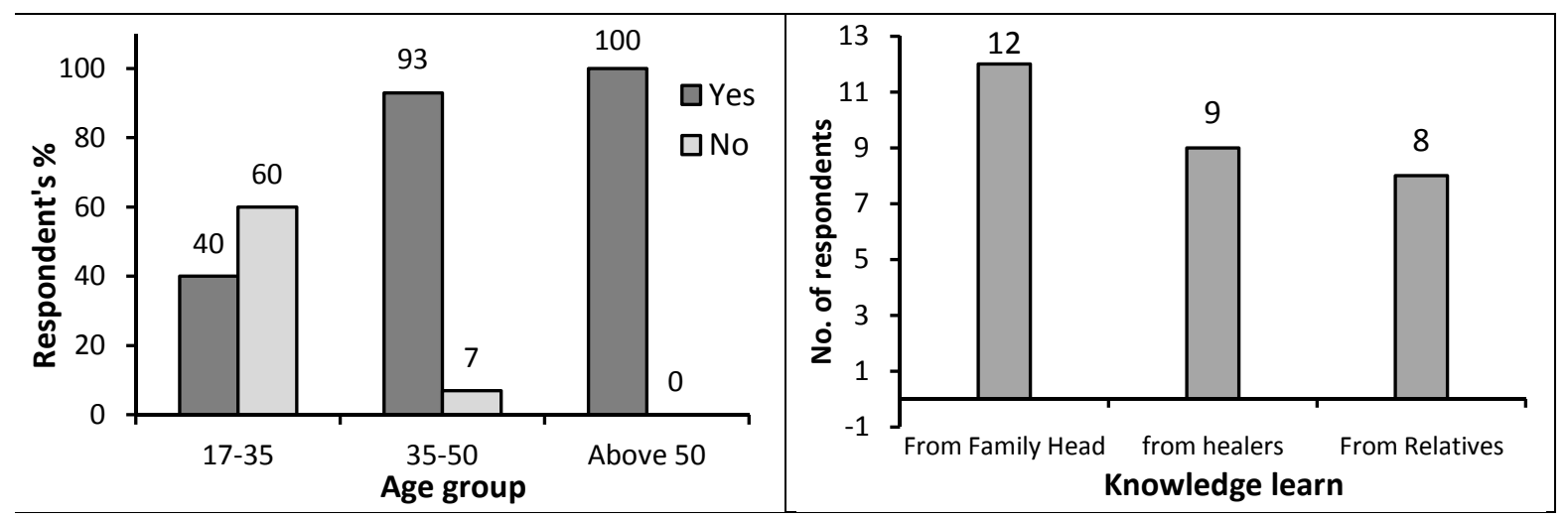

Figure 3. Age and knowledge relation in medicine preparation.

Figure 4. Knowledge transformation about use of medicinal plants.



Figure 5. Response on conservation and management of medicinal plants.

\section{Conclusion}

Raji People of the study area still have a strong knowledge and belief in the efficacy and success of traditional healing practices. The elderly people have deep knowledge but the knowledge level differ with respect to age and generation. Regarding the ignorance of young generation towards traditional knowledge there seems danger of extinction of such practices. The results of the present study provide evidence of indigenous knowledge and uses of common medicinal plants for the treatment of various ailments by Raji people. Therefore, it is essential to conserve such a wealth of information existed still among the Raji people.

\section{Acknowledgements}

The author is grateful to University Grants Commission, Nepal for providing financial support and deeply indebted to the Raji people of Uttarganga VDC and Chhinchu VDC of Surkhet district. Special thanks to Sanjeev Shrestha (Birendranagar), Ashok Raji (Uttarganga) and Manju Raji (Chhinchu) for their cooperations in the present study. 


\section{References}

Acharya, R. \& K.P. Acharya. 2009. Ethnobotanical study of medicinal plants used by Tharu community of Parroha VDC, Rupandehi district, Nepal. Scientific World 9: 81-85.

Acharya, S.K. 1996. Folk uses of some medicinal plants of Pawanagar, Dang district. Journal of Natural History Museum, Nepal. 15(1-4): 25-36.

Benzet, B., J. Cevallos, F. Santana, J. Rosales \& S. Graf. 2000. Losing knowledge about plant use in the Sierra De Manantlan Biospehre Reserve, Mexico. Economic Botany 54: 183191.

Bhatarai, N.K. 1989. Traditional phytotherapy among the Sherpas of Helambu, central Nepal. $J$. Ethnopharmacol. 27(1/2): 45-54.

Bhattachan, K.B. 2000. Environmental Ethics and Indigenous Peoples. Kathmandu, Nepal.

Gautam, R. \& A.K. Thapa Magar. 1994. Tribal ethnography of Nepal, Vol. 1. Delhi Book Faith, India.

Hara, H., A.H. Charter \& L.H.J. Williams. 1982. An enumeration of the flowering plants of Nepal. Vol. III. London: British Natural History Museum.

Joshi, R., K. Basnyat \& R. Ranjit. 1999. Study on some wild edible plants of Chepangs. Abstract, BSC-087 In: III National Conference on Science and Technology: Abstracts, March 8-11, 1999. Royal Nepal Academy of Science and Technology, Kathmandu, Nepal. pp. 115.

Manandahar, N.P. 1990. Traditional phytotherapy of Danuwar tribe of Kamalkhong in Sindhuli district, Nepal. Fitoterapia, Italy. 61(4): 325-332.

Manandhar, N.P. 1991. Medicinal plantlore of Tamang tribe of Kabhrepalanchowk district, Nepal. Eco. Bot. 45(1): 58-71.

Manandhar, N.P. 1998. Native phytotherapy among the Raute tribe of Dadeldhura district, Nepal. J. Ethnopharmacology 60(3): 199-206.

Martin, G.J. 1995. Ethnobotany: a Methods Manual. Chapman \& Hall, London, UK.

Polunin, O. \& A. Stainton. 1984. Flowers of the Himalaya. New Delhi: Oxford University Press.

Press, J.R., K.K. Shrestha \& D.A. Sutton. 2000. Annotated checklist of the Flowering Plants of Nepal. The Natural History Museum, London, UK.

Rai, S.K. 2004. Medicinal plants used by Meche people of Jhapa district, eastern Nepal. Our Nature 2: 27-32.

Siwakoti, M. \& S. Siwakoti. 1998. Ethnomedicinal uses of plants among the Limbu, Morang district, Nepal. Ecoprint 5(1): 79-84. 